\title{
Evaluation of the wound healing property of Commiphora guidottii Chiov. ex. Guid.
}

\author{
Michael Gebrehiwot ${ }^{1}$, Kaleab Asres ${ }^{1 *}$, Daniel Bisrat ${ }^{1}$, Avijit Mazumder $^{2}$, Peter Lindemann ${ }^{3}$ and Franz Bucar ${ }^{4}$
}

\begin{abstract}
Background: The traditional use of the oleo-gum-resin of Commiphora guidottii Chiov. ex. Guid., which is commonly called scented myrrh, for topical treatment of wound is well documented. The major objective of the present study was to investigate the essential oil and resin obtained from C. guidottii for their potential wound healing properties. Due to their influence on the wound healing process, the anti-inflammatory and antimicrobial activities of scented myrrh have also been investigated.

Methods: Powdered oleo-gum-resin of C. guidottii was steam-distilled to obtain essential oil, and the resin was extracted from the marc with $\mathrm{MeOH}$ and filtered. The TLC fingerprint profile of the resin has been recorded by using silica gel $\mathrm{GF}_{254}$ as stationary phase. The essential oil components were identified and quantified by GC-MS. Ointments prepared from the essential oil (4 \% v/w) and the resin ( $5 \% \mathrm{w} / \mathrm{w})$ were used for wound healing activity tests. Toxicity of the formulated ointments was investigated according to Draize skin irritation test. Acute anti-inflammatory effect in mice was evaluated using carrageenan induced mouse hind paw oedema model. Antimicrobial activity tests were carried out using disk diffusion and broth dilution techniques against 21 pathogenic bacterial and 4 fungal strains.

Results: Ointment formulations of both the oil and resin were found to be non-irritant at the concentrations used and showed significant $(p<0.05-0.001)$ increase in wound contraction rate, shorter epithelization time and higher skin breaking strength as compared to the negative control. Overall, the antibacterial and antifungal activities of the oil and resin were comparable with the standard antibiotics ciprofloxacin and griseofulvin, respectively.
\end{abstract}

Conclusion: The results confirm that scented myrrh possesses genuine wound healing activity supporting the traditional use of the plant.

Keywords: Commiphora guidottii, Essential oil, Resin, Wound healing, Anti-inflammatory, Antimicrobial

\section{Background}

The skin being a protective barrier against the outside world, any break to it must be rapidly and efficiently mended [1]. When acute wound healing does not progress in an orderly and timely manner, complications can occur; incisions can dehisce; hernias can form; anastomoses can leak; and fistulae can develop [2]. Many of the available drugs for wound management are not only expensive but also pose problems such as allergy and drug resistance [3, 4]. By and large, phytomedicines for wound healing are not only cheap and affordable, but are also safe. Thus, one-

\footnotetext{
* Correspondence: kaleab.asres@aau.edu.et

'Department of Pharmaceutical Chemistry and Pharmacognosy, School of Pharmacy, College of Health Sciences, Addis Ababa University, P.O. Box 1176, Addis Ababa, Ethiopia

Full list of author information is available at the end of the article
}

third of all traditional medicines in use are for the treatment of wounds and skin disorders, which is a very high figure as compared to only $1-3 \%$ of modern drugs [5].

Commiphora guidottii Chiov. ex. Guid. (Burseraceae) is a shrub or tree growing up to $5 \mathrm{~m}$ tall; has greenish or brownish peeling bark and is native to Ethiopia and Somalia. It is fairly widespread in Somalia and in adjacent parts of Ogaden in Ethiopia. Its vernacular name is "hadi" (sometimes spelled "hedi" or "hethi" by collectors) in all areas where it is distributed. However, in Central Somalia it is also known as "dunkaal". The oleo-gumresin of C. gudottii, which is otherwise known as scented myrrh, is commonly called "habakhadi" in Somalia and "abeked" (Amharic) in Ethiopia [6], where it is added to cattle feed to improve milk production. The Somali 
people also use it as a remedy for diarrhoea and stomach complaints, to facilitate withdrawal of the placenta after childbirth and for topical treatment of wounds [6-8].

Literature review reveals that the essential oil of C. guidottii consists of mono- and sesquiterpens [9]. Bioassay guided fractionation of the EtOAc extract of the resin resulted in the isolation of the sesquiterpene (+)-T-cadinol, as the major bioactive component of the plant with spasmolytic and bactericidal effects [10,11]. Although less potent than T-cadinol with respect to their smooth muscle relaxing properties in the rat aorta, additional minor compounds such as cadinane, guaiane, oplopane and eudesmane were also isolated from the more polar fraction of scented myrrh [12].

In an attempt to prove the traditional uses of scented myrrh for the treatment of wounds, Claeson et al. [11] investigated the antibacterial effects of its constituents against Staphylococcus aureus, which is one of the most common bacterial wound pathogens. Moreover, the use of the plant by traditional healers in Somalia for the treatment of general stomach complaints necessitated the experimental assessment of the latex or its components for their effects against cholera toxin-induced intestinal hyper secretion in mice [7] and also for their inhibitory effects on contractile responses in the isolated guinea-pig ileum [10]. The above studies confirmed that the constituents of scented myrrh possess genuine bactericidal and antidiarrhoeal activities. However, to date, there appears to have been no report on scientific investigation of its wound healing properties.

The main objective of the present study was therefore to evaluate the wound healing activity of the essential oil and resin obtained from scented myrrh using in vivo and in vitro experiments. Anti-inflammatory and antimicrobial actions of these plant products have also been investigated since such effects are crucial for wound healing process.

\section{Methods}

\section{Plant material}

The oleo-gum-resin of C. guidottii (gum opopponax first grade), collected from Ogaden Region, in eastern Ethiopia from September - October 2010, was purchased from the Ethiopian Natural Gum Processing and Marketing Enterprise (ENGPME), Addis Ababa, Ethiopia. According to the enterprise, first grade refers to the plant material that has passed through serious grabbling processes and almost free from foreign matters and contaminants.

\section{Experimental animals}

Healthy Swiss albino mice of either sex (26-35 g and age of 9-11 weeks) were procured from the animal house of the Ethiopian Health and Nutrition Research
Institute (EHNRI) Addis Ababa, Ethiopia. Adult Wistar albino rats (weighing 150-200 $\mathrm{g}$ and age of 10-11 weeks) were obtained from the animal house of the School of Pharmacy (SoP), Addis Ababa University (AAU). All animals were outbred strains but undergone several generations of inbreeding. They were not subjected to any drug or test substance investigation prior to the experiments, and were bred selectively in the ratio of 1 male to 3 females, and kept in a $12 \mathrm{~h}$ light/dark cycle and at room temperature, provided with commercial pelleted ration and clean water ad libitum. The animals were cared for feeding, watering, housing, analgesia, and any health problems at all time points and especially during experimental periods. They were acclimatized for one week before the study, and during the experiment the animals were housed individually in clean plastic cages in the SoP animal house so as to avoid biting and possible wound scratch to each other. All the animals survived and were fit to conduct the experiments. They were then assigned to either treatment or control groups by simple random allotment using lottery method. The same was done for treating animals within the same group. All the experiments were conducted in Pharmacognosy laboratory of SoP in accordance with the internationally accepted laboratory animal use, care and guideline [13] and approved by the institutional Ethics Review Board of the SoP, AAU. At the end of the experiment, animals were killed using cervical dislocation.

\section{Microbial strains}

The samples were tested against the Gram-negative bacterial strains: Escherichia coli CD/99/1, E. coli K88, E. coli K99, E. coli 306, E. coli LT37, E .coli 872, E. coli ROW 7/12, E. coli 3:37C, Salmonella typhi Ty2, Shigella boydii D13629, S. dysentery 1, S. dysentery 8, S. flexneri Type 6, S. soneii 1, Vibrio cholerae 85, V. cholerae 293, V. cholerae 1313 and $V$. cholerae 1315. The Gram-positive bacterial strains used were: Bacillus pumilus 82, B. subtilis ATCC 6633 and Staphylococcus aureus ML 267. All the bacterial strains were procured from the Department of Technology, Jadavpur University; Central Drugs Laboratory, Kolkata and Institute of Microbial Technology, Chandigarh, India. The stains were first checked for purity on the basis of standard microbiological, cultural and biochemical tests and then used for their sensitivity towards the test samples.

Antifungal activity was performed on the fungal pathogens: Aspergillus niger ATCC 6275, Candida albicansATCC 10231, Penicillium funiculosum NCTC 287 and P. notatum ATCC 11625. All the fungal strains were procured from the Central Drugs Laboratory, Kolkata, India. 


\section{Extraction and fractionation}

Crushed air-dried oleo-gum-resin (200 g) of C. guidottii was steam-distilled for $5 \mathrm{~h}$ to obtain the essential oil. After removal of the oil, the marc left was extracted with $\mathrm{MeOH}$ and filtered. The filtrate was then partitioned (3x) with equal amount of $n$-hexane using a separatory funnel, to remove the remaining oil components from the resin. The methanolic layer was then dried in a drying oven at a temperature not exceeding $40{ }^{\circ} \mathrm{C}$ and the percentage yield of the resin was calculated [14].

\section{Thin layer chromatography (TLC)}

TLC was run on analytical Silica gel $60 \mathrm{~F}_{254}$ (Merck) plates using a mixture of toluene and EtOAc (98:2) as a solvent system. The distance from the base line up to the solvent front was adjusted to $8 \mathrm{~cm}$ and $10 \mu \mathrm{L}$ each of the resin $(5 \mu \mathrm{L} / \mathrm{mL}$ in ethanol) and the reference compound (thymol, $1 \mathrm{mg} / \mathrm{mL}$ in ethanol) were applied $2 \mathrm{~cm}$ from the bottom of the plate. After the plates were developed, the spots were detected in day light or under UV light of long wavelength $(366 \mathrm{~nm}$ ) after spraying with anisaldehyde - sulfuric acid reagent followed by heating at $110{ }^{\circ} \mathrm{C}$ for $10 \mathrm{~min}$.

\section{Gas chromatography-mass spectrometry (GC-MS)}

Capillary GC-MS was performed on a Shimadzu 2010 (Shimadzu Co., Japan) using HP5-MS (Supreme-5 ms, CS - Chromatographie Service $\mathrm{GmbH}$, Langerwehe Germany $30 \mathrm{~m} \times 0.32 \mathrm{~mm}$ ) column. Conditions: carrier gas hydrogen $(1.5 \mathrm{~mL} / \mathrm{min})$; sample diluted with $\mathrm{MeOH}$ (1:1000); splitless; injection temp. $300{ }^{\circ} \mathrm{C}$; oven $40^{\circ}$ for $3 \mathrm{~min}$ isothermal; $40-150^{\circ}$ at $6^{\circ} \mathrm{min}^{-1}$; 150 $320^{\circ}$ at $10{ }^{\circ} \mathrm{C} \mathrm{min}{ }^{-1}$ and then hold for $3 \mathrm{~min}$. RIs were calculated using co-chromatographed standard n-alkanes (C9-C29). Compounds were identified by mass spectral comparison with a commercial database (Wiley $138 \mathrm{~K}$ mass spectral library) and laboratory's own database. Spectral data were compared with linear retention indices published in the literature [15-18].

\section{Phytochemical analysis}

The resin of C. guidottii was screened for secondary metabolites such as flavonoids, terpenoids, polyphenols, tannins, saponins and steroidal compounds according to the method described in the literature $[14,19,20]$.

\section{Toxicity studies}

\section{Acute oral toxicity}

Acute oral toxicity was studied according to the method described by Gatsing et al. [21]. Briefly, Swiss albino mice of either sex were divided into four groups of six animals each. All animals were fasted for $15 \mathrm{~h}$ before administration of the test samples. Animals were given 1000, 3000 and $5000 \mathrm{mg} / \mathrm{kg}$ of the resin to the corresponding groups, by suspending the sample in $2 \%$ Tween 80 , while the negative control group was given $2 \%$ Tween 80 only. The animals were observed for any behavioural changes (like locomotion, reaction to noise, reaction to pinch, reactivity and state of excrement) during the first $3 \mathrm{~h}$ after a single oral dose administration of the test samples, and were given free access to food and water. Deaths, if any, were counted within the first $48 \mathrm{~h}$ after administration of the extracts.

\section{Skin irritation test}

Skin irritation test was carried out using occluded dermal irritation test [22] with slight modification. Two groups of rats (each group containing six animals) were employed for this test and two areas on the dorsal side of each rat on each side of the vertebrae $(1 \mathrm{~cm}$ from the midline of the vertebral column) were shaved and marked before the experiment. One area was for test sample ointment and the other was left untreated to be used for comparison. Topical ointment preparation of the oil and resin was applied to the respective group. Immediately after, the area was covered by dressing gauze over which a plastic sheet (occlusive material) was placed. The covering was loosely held in contact with the skin by means of a non-irritating adhesive tape and tied across the diameter of the back of the rats with an elastic bandage. After $24 \mathrm{~h}$ of exposure period, the elastic bandage, the adhesive plaster, the plastic sheet and the gauze were removed by taking care not to damage the skin, and the test site was rinsed with distilled water. The animals were examined for the presence of erythema and oedema according to Draize dermal irritation scoring system [23] at intervals of 1, 24, 48 and $72 \mathrm{~h}$. The degree of erythema and oedema was determined based on the scores shown in Table 1.

Primary irritation index (PII) was calculated for the test samples according to the formula shown below [22].

Table 1 Erythema and oedema scores used to determine the primary irritation index

\begin{tabular}{ll}
\hline Erythema & Value \\
\hline No erythema & 0 \\
Very slight erythema (barely perceptible) & 1 \\
Well-defined erythema & 2 \\
Moderate to severe erythema & 3 \\
Severe erythema (beef redness) & 4 \\
Oedema formation & Value \\
No oedema & 0 \\
Very slight oedema (barely perceptible) & 1 \\
Slight oedema (edges of area well-defined by definite raising) & 2 \\
Moderate oedema (raised approximately 1 mm) & 3 \\
Severe oedema (extending beyond the area of exposure) & 4 \\
\hline
\end{tabular}




$$
\begin{aligned}
\text { PII } & =\frac{\sum(\text { Erythema at } 1,24,48 \text { and } 72 h)}{\text { No of test sites } \times 4 \text { scoring intervals }} \\
& +\frac{\sum(\text { Oedema at } 1,24,48 \text { and } 72 \mathrm{~h})}{\text { No of test sites } \times 4 \text { scoring intervals }}
\end{aligned}
$$

If irreversible alteration of the dermal tissue is noted in any animal, which include ulceration and clear necrosis or signs of scar tissue, the test item is classified as corrosive in which case Draize classification was not applicable.

\section{Ointment formulation}

Simple ointment base was prepared according to the British Pharmacopoeia [24] using hard paraffin, cetostearyl alcohol, white soft paraffin and wool fat. The essential oil $(4 \mathrm{~mL})$ and the resin $(5 \mathrm{~g})$ were separately incorporated into portions of the simple ointment to make $4 \%(\mathrm{v} / \mathrm{w})$ oil and $5 \%(\mathrm{w} / \mathrm{w})$ resin ointments of uniform consistency and smooth texture.

\section{In vivo wound healing models \\ Excision wound model}

Four groups of rats of either sex containing six per group (3 male and 3 female) were anaesthetized with diethyl ether. Diethyl ether was used as inhalational anesthesia using desiccators, and depth of anesthesia was monitored using vital reflexes. Circular wound of area $540 \mathrm{~mm}^{2}$ was inflicted and left undressed. Then, $4 \%(\mathrm{v} / \mathrm{w})$ essential oil ointment or $5 \%(\mathrm{w} / \mathrm{w})$ resin ointment for the experimental groups; $0.2 \%(\mathrm{w} / \mathrm{v})$ nitrofurazone ointment and simple ointment BP for the positive and negative control groups, respectively, were topically applied on a daily basis until the wound healed completely. Wound contraction was assessed by tracing the wound area on transparent paper (subsequently transferring it to a graph paper) every other day, and the change in wound area was calculated [25]:

$$
\% \text { Wound contraction }=\frac{\text { Healed area }\left(\mathrm{mm}^{2}\right)}{540 \mathrm{~mm}^{2}} \times 100
$$

where, healed area $=$ original wound area $\left(540 \mathrm{~mm}^{2}\right)-$ present wound area.

Number of days required for complete falling of scab without any residual raw wound, which indicates the period of epithelization, was noted [26].

\section{Incision wound model}

Five groups of mice containing six animals in each group were anaesthetized and longitudinal paravertebral incisions were made $1 \mathrm{~cm}$ from the midline of the vertebral column [27]. A full aseptic measure was not taken and no local or systemic antimicrobials were used throughout the experiment. The wound was closed with interrupted suture, $1 \mathrm{~cm}$ apart with the help of black silk surgical thread and straight needle [26]. Ointments of the oil $(4 \%, \mathrm{v} / \mathrm{w})$ or the resin $(5 \%, w / w)$ were applied topically on the respective test groups, while $0.2 \%(\mathrm{w} / \mathrm{v})$ nitrofurazone and simple ointment were applied for the positive and negative controls, respectively, for ten days (on a daily basis). This was done every morning at 9:00 a.m. One of the five groups was left untreated. The suture was removed on the $7^{\text {th }}$ day and skin breaking strength was measured by continuous water flow method on day 10 after the animals were euthanized $[25,28]$. Percentage of tensile strength was calculated using the following formula [29]:

$$
\begin{gathered}
\text { \% Tensile strength }(\mathrm{TS}) \text { of test sample }=\frac{\text { TS of test sample-TS s.o }}{\text { TS s.o }} \times 100 \\
\text { \%Tensile strength }(\mathrm{TS}) \text { of reference }=\frac{\text { TS of reference-TS s.o }}{\text { TS s.o }} \times 100 \\
\text { \%Tensile strength }(\mathrm{TS}) \text { of s.o }=\frac{\text { TS s.o-TS l.u }}{\text { TS l.u }} \times 100
\end{gathered}
$$

where, s.o and l.u stand for simple ointment treated and left untreated groups, respectively.

\section{Hydroxyproline assay}

Hydroxyproline $(0.05 \mathrm{~g})$ was dissolved in water and diluted to about $400 \mathrm{~mL}$ with water. Concentrated $\mathrm{HCl}$ $(20 \mathrm{~mL})$ was added and the solution was made up to $500 \mathrm{~mL}$ with water. The solution $(100 \mu \mathrm{g} / \mathrm{mL})$ was then diluted to give 5,10 and $15 \mu \mathrm{g}$ of hydroxyproline $/ \mathrm{mL}$. Triplicate solutions of each of these concentrations and blank solutions were prepared. One $\mathrm{ml}$ of $0.05 \mathrm{M} \mathrm{CuSO}_{4}$ was added into each test tube, followed by the addition of $1 \mathrm{~mL}$ of $2.5 \mathrm{~N} \mathrm{NaOH}$, and the tube contents were mixed by gentle swirling. The tubes were placed in a water bath at $40{ }^{\circ} \mathrm{C}$ for about $5 \mathrm{~min}$ and then $1 \mathrm{~mL}$ of $6 \%$ $\mathrm{H}_{2} \mathrm{O}_{2}$ was added. The tubes were left in a bath for $10 \mathrm{~min}$ with occasional swirling and cooled with tap water, then $4 \mathrm{~mL}$ of $3 \mathrm{~N} \mathrm{H}_{2} \mathrm{SO}_{4}$ and $2 \mathrm{~mL}$ of $5 \%$ dimethylaminobenzaldehyde (DMAB) solution were added by swirling after each addition. Caps were placed on tubes, which were kept in a water bath at $70{ }^{\circ} \mathrm{C}$ for $16 \mathrm{~min}$. The solutions were cooled, mixed and their absorbance measured against the blank solution at wavelength of $572 \mathrm{~nm}$ in $1 \mathrm{~cm}$ cells [30] and calibration curve was constructed.

Hydroxyproline assay was performed by inducing circular wound with approximate area of $300 \mathrm{~mm}^{2}$ using the procedure described in excision wound model. The wounds were treated with topical application of the oil, resin, $0.2 \%$ nitrofurazone or simple ointment for 10 days [28]. On the $11^{\text {th }}$ post wounding day, the animals from each group were euthanized and the wound tissue was excised, weighed, and dried in an oven at $70{ }^{\circ} \mathrm{C}$ for $18 \mathrm{~h}$, and the dry weights were noted. The tissues were treated in the same way as the standard hydroxyproline was 
treated, and absorbance was measured at $572 \mathrm{~nm}$ using a spectrophotometer (Jenway Model 6500, England). The amount of hydroxyproline in the samples was calculated by using the following equation, which was obtained from the calibration curve of the standard hydroxyproline [31]:

$$
\mathrm{A}=0.0058 \times \mathrm{C}+0.0067 \text { OR } \mathrm{C}=\frac{\mathrm{A}-0.0067}{0.0058}
$$

where, $\mathrm{A}$ is absorbance and $\mathrm{C}$ is concentration.

\section{Anti-inflammatory activity}

Mouse paw oedema model was used to determine the acute anti-inflammatory activity of the test substances. Following overnight fasting with free access to water, the basal volume of the right hind paw of each mouse was determined before administration of any drug using plethysmometer (Ugo Basile, 7140 Italy) [32]. Then, the animals were divided into five groups (six animals per group), such that the mean volumes of the different groups were similar. Vehicle, the standard drug (indomethacin $10 \mathrm{mg} / \mathrm{kg}$ ), and the resin in three dose levels $(150,300$ and $600 \mathrm{mg} / \mathrm{kg})$ were administered orally to the respective group, $1 \mathrm{~h}$ before carrageenan injection. The resin and indomthacin were separately suspended in $2 \%$ Tween 80 . Paw swelling was induced by sub-plantar injection of $0.05 \mathrm{~mL}$ of $1 \%$ carrageenan in $0.9 \%$ saline $(\mathrm{w} / \mathrm{v})$ into the right hind paw. Thereafter, paw oedema was measured at 1, 2, 3 and $4 \mathrm{~h}$ after carrageenan injection using plethysmometer [33]. Percent inhibition of oedema was calculated using the formula:

$$
\% \text { Oedema inhibition }=1-\left(\frac{\text { Oedema of test sample }}{\text { Oedema of control }}\right) \times 100
$$

\section{Antimicrobial activity \\ Antibacterial test}

Zones of inhibition produced by the samples were determined by disc diffusion technique, and compared with those produced by ciprofloxacin [34]. The resin and the oil were separately dissolved in dimethylsulfoxide (DMSO), (DMSO was found to be inactive at the concentration used). Serial nutrient agar plates were prepared and incubated at $37^{\circ} \mathrm{C}$ for $24 \mathrm{~h}$ to check for any contamination. Sterile filter paper discs of $6 \mathrm{~mm}$ diameter were soaked in stock solution $(200 \mu \mathrm{g} / \mathrm{mL})$ of the samples (each $6 \mathrm{~mm}$ disc was shown to absorb $25 \mu \mathrm{L}$ of the sample solution of reference drug stock solution in order to be saturated) and placed in the appropriate position on the surface of the plate flooded with $24 \mathrm{~h}$ old culture grown on nutrient broth, marked as quadrant on the back of the Petri dishes. They were then incubated at $37 \mathrm{oC}$ for $24 \mathrm{~h}$ and the diameters of zone of inhibition were measured in $\mathrm{mm}$. A similar procedure was adopted for pure ciprofloxacin (dissolved in water at a concentration of $200 \mu \mathrm{g} / \mathrm{mL}$ ) and the zone of inhibition was compared accordingly. The minimum inhibitory concentrations (MICs) of the test samples were also determined by the checkerboard technique using nutrient agar media [35].

\section{Antifungal test}

Antifungal activity was first evaluated by estimation of the MIC of the test substances against the fungal pathogens, followed by the disc diffusion method, using griseofulvin (at a concentration of $2000 \mu \mathrm{g} / \mathrm{mL}$ ) as a reference standard on Sabourds Dextrose Agar (SDA) medium according to CLSI [36]. The concentrations selected for MIC determination ranges from 50 to $2000 \mu \mathrm{g} / \mathrm{mL}$ and the zones of inhibition were studied at the highest MIC value as described by Mitchell and Carter [34].

\section{Statistical analysis}

Raw data obtained from most of the experiments were expressed as mean \pm SEM (standard error of the mean). Results were statistically analyzed using Microsoft excel 2010 and one-way ANOVA followed by Post Hoc Tukey and Dunnett t-tests using SPSS version 20 software. Results were considered as significant at $P<0.05$.

\section{Results}

\section{Extraction and chromatography}

Steam distillation of the oleo-gum-resin of C. guidottii followed by maceration with methanol yielded a pale yellow oil $(2.8 \% \mathrm{v} / \mathrm{w})$, and a reddish brown resin $(39 \%$ $\mathrm{w} / \mathrm{w})$, respectively. Preliminary phytochemical screening indicated the presence of terpenoids, steroids and phenolic compounds in the resin. These results were consistent with previous report of Hanuš et al. [9]. TLC fingerprint profile of the resin is depicted in Fig. 1. Chemical composition of the essential oil of C. guidottii was studied using GC-MS and the results are summarized in Table 2.

The relative percentage of the 29 compounds (about $98.98 \%$ of the oil) identified in the oil is also shown.

\section{Toxicity studies}

In acute toxicity study, the resin killed more than $50 \%$ of the animals at a dose of $5000 \mathrm{mg} / \mathrm{kg}$, while no mortality was observed at a dose of $3000 \mathrm{mg} / \mathrm{kg}$, except for some decrease in locomotor activity. This indicates that the dose causing $50 \%$ death of the animals $\left(\mathrm{LD}_{50}\right)$ is near $3000 \mathrm{mg} / \mathrm{kg}$, indicating good safety margin. This result complements the previous report which confirmed that the non-polar extracts of the resins of C. guidottii are non-toxic to experimental animals up to the tested dose of $1.2 \mathrm{~g} / \mathrm{kg}$ [37]. 


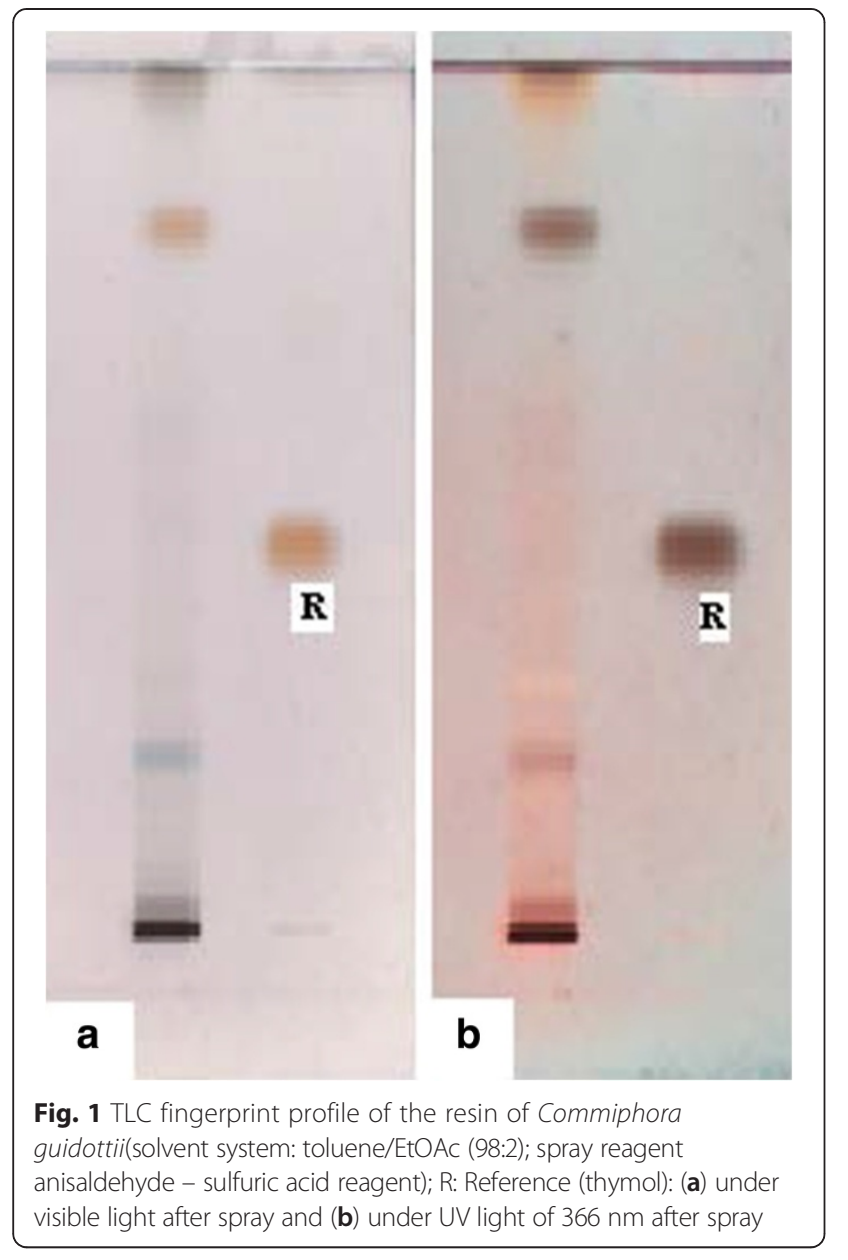

Both the formulated oil and resin of $C$. guidottii were found to cause no erythema or oedema. Therefore, their PII values were zero implying the non irritant nature of the test samples as per the dermal irritation scoring system of Draize [23] and Environmental Protection Authority [36].

\section{Wound healing activity \\ Wound contraction and period of epithelization}

In the present study, diethyl ether was used as an anaesthetic agent because of its availability, rapid recovery, return from anaesthetic hypothermia, lower incidence of death, quick elimination from the lungs and relative technical ease of administration. Moreover, diethyl ether has a smaller impact on the receptors located in the membrane of erythrocytes maintaining a stable immune function in mice, which is a big advantage to our work since immunosuppression could have seriously affected our results.

As shown in Fig. 2, wound contraction was promoted till day 16 in both test substance and standard ointment treated groups. The test samples facilitated wound contraction significantly $(p<0.05)$ from day 8 to 16 as compared to the negative control, and the difference was
Table 2 Composition of the essential oil of Commiphora gudottii oleo-gum-resin

\begin{tabular}{|c|c|c|c|}
\hline No. & Compound $^{\mathrm{a}}$ & $\mathrm{RI}^{\mathrm{b}}$ & Percentage \\
\hline 1 & cis- $\beta$-Ocimene & 1038 & 0.15 \\
\hline 2 & trans- $\beta$-Ocimene & 1044 & 6.71 \\
\hline 3 & Rosefuran & 1100 & 0.26 \\
\hline 4 & a-Pinene oxide & 1101 & 0.47 \\
\hline 5 & 6-Methyl-3,5-heptadiene-2-one & 1104 & 0.29 \\
\hline 6 & Limona ketone & 1125 & 1.19 \\
\hline 7 & cis-Myroxide & 1141 & 0.67 \\
\hline 8 & Limonen-10-ol & 1288 & 0.50 \\
\hline 9 & 1-Decanol & 1328 & 0.53 \\
\hline 10 & a-Copaene & 1374 & 0.18 \\
\hline 11 & $\beta$-Bourbonene & 1387 & 0.61 \\
\hline 12 & $\beta$-Elemene & 1389 & 3.87 \\
\hline 13 & a-Santalene & 1416 & 19.54 \\
\hline 14 & trans-a-Bergamotene & 1432 & 9.30 \\
\hline 15 & a-Humulene & 1452 & 0.45 \\
\hline 16 & cis- $\beta$-Farnesene & 1454 & 0.62 \\
\hline 17 & $\beta$-Santalene & 1462 & 0.71 \\
\hline 18 & Germacrene D & 1484 & 0.75 \\
\hline 19 & Sesqiterpene ${ }^{c}$ & 1494 & 2.29 \\
\hline 20 & a-Selinene & 1498 & 0.97 \\
\hline 21 & Curzerene & 1499 & 11.38 \\
\hline 22 & a-Bisabolene & 1506 & 2.33 \\
\hline 23 & Sesqiterpene ${ }^{c}$ & 1570 & 1.23 \\
\hline 24 & Sesqiterpene ${ }^{c}$ & 1611 & 4.77 \\
\hline 25 & $108,214,274^{c}$ & 1626 & 0.98 \\
\hline 26 & Furanoeudesma-1,3-diene & 1654 & 18.63 \\
\hline 26 & Isofuranodiene & 1658 & 6.76 \\
\hline 27 & Furanodiene & 1690 & 1.28 \\
\hline 28 & 8-a-Ethoxyisofuranodiene & 1705 & 0.96 \\
\hline \multirow[t]{2}{*}{29} & 8-a-Methoxyfurandione & 1848 & 0.60 \\
\hline & Total (\%) & & 98.98 \\
\hline
\end{tabular}

${ }^{a}$ Compounds listed in order of elution; ${ }^{\mathrm{b}} \mathrm{RI}$ (retention index) measured relative to n-alkanes (C9-C28) on HP5-MS column under conditions listed in the Experimental section; ${ }^{\mathrm{C} C o m p o u n d}$ not identified (figures represent prominent peaks in the mass spectrum)

insignificant with nitrofurazone. Time for complete epithelization was significantly $(p<0.05)$ shorter in test sample and nitrofurazone treated groups as compared to the negative control (Table 3). However, there was no significant difference between nitrofurazone and resin, between nitrofurazone and the oil, and between resin and the oil.

\section{Tensile strength}

The wound breaking strength of all animals treated with test samples showed significant $(p<0.05)$ difference when 


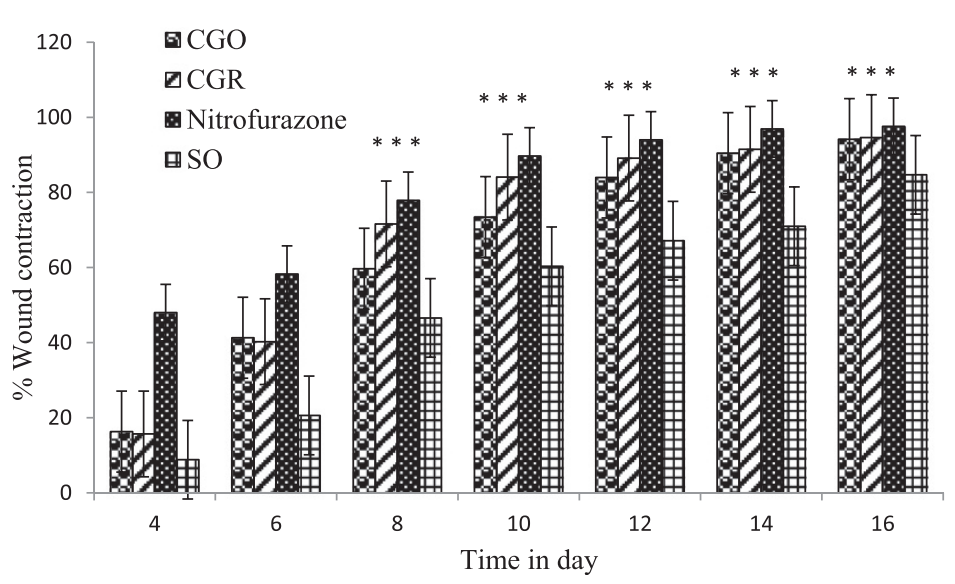

Fig. 2 Percentage contraction of the wound of animals treated with ointments containing $4 \%(v / w)$ essential oil or $5 \%$ (w/w) resin of Commiphora guidottii ("Significant ( $p<0.05)$; CGO: C. guidottii essential oil; CGR: C. guidottii resin; SO: Simple ointment)

compared to the animals that are left untreated. Particularly, the resin showed significant $(p<0.05)$ difference in tensile strength when compared to the simple ointment treated groups. Animals treated with simple ointment increased the tensile strength by about $19.73 \%$, which failed to reach statistical significance, when compared to the untreated controls (Table 4).

\section{Hydroxyproline assay}

Table 5 shows the hydroxyproline content in the granulation tissues of the test animals on day 11. Hydroxyproline levels of oil and resin ointment treated groups were significantly $(p<0.05)$ increased as compared to the simple ointment treated group.

\section{Anti-inflammatory activity}

After administration of carrageenan, resin and indomethacin treated animals showed significant $(p<0.001)$ reduction of oedema as compared to the negative control (Table 6). However, there was no significant difference with the standard drug indomethacin in any course of the study.

Table 3 Effect of topical application of ointments containing 4 $\%(v / w)$ essential oil or $5 \%$ (w/w) resin of Commiphora guidottiion wound epithelization period of excision wound model in comparison with nitrofurazone and simple ointments

\begin{tabular}{ll}
\hline Group & Period of epithelization (day) \\
\hline Essential oil & $22.42 \pm 0.61^{*}$ \\
Resin & $23.50 \pm 0.72^{*}$ \\
Nitrofurazone & $20.67 \pm 0.33^{* *}$ \\
Simple ointment & $25.67 \pm 0.42$ \\
\hline
\end{tabular}

"The mean value is significant $(p<0.01)$ and $\left.{ }^{* *} p<0.001\right)$ when compared with simple ointment treated group; $N=6$; Results are expressed as mean \pm SEM

\section{Antimicrobial activity}

Zone of inhibition and MIC values of the resin and oil against different bacterial strains are shown in Table 7. The Gram-negative bacteria including all strains of $E$. coli and $V$. cholerae, as well as S. typhi Ty2 were found to be the most inhibited bacterial pathogens by both the oil and resin of C. guidottii. The remaining Gram-negative bacterial strains namely, all strains of Shigella and the Gram-positive bacterial strains: B. pumilus, and $B$. subtilis were inhibited moderately. The oil and resin also exhibited good antibacterial effect against $S$. aureus with MIC values of 25 and $50 \mu \mathrm{g} / \mathrm{mL}$, respectively. In general, the test substances showed low MIC $(\leq 100 \mu \mathrm{g} / \mathrm{mL})$ values against most of the tested pathogenic bacterial strains indicating their broad spectrum of action.

Similarly, the antifungal activity was studied and their MIC values determined (Table 8). Lowest MIC value was recorded for the oil $(400 \mu \mathrm{g} / \mathrm{mL})$ on C. albicans ATCC 10231. Overall, both the oil and the resin were $68.8-88.9$ $\%$ as active as the standard antifungal agent griseofulvin.

Table 4 Effect of topical application of ointments containing $4 \%(\mathrm{v} / \mathrm{w})$ essential oil or $5 \%(\mathrm{w} / \mathrm{w})$ resin of Commiphora guidottiion wound tensile strength of incision wound model in comparison with nitrofurazone and simple ointment

\begin{tabular}{lll}
\hline Group & Tensile strength $(\mathrm{g})$ & \% Tensile strength \\
\hline Essential oil & $234.67 \pm 23.40^{*}$ & 29.42 \\
Resin & $293.83 \pm 53.50^{*_{a}}$ & 78.17 \\
Left untreated & $123.00 \pm 0.41$ & - \\
Nitrofurazone & $319.83 \pm 32.26^{*_{a}}$ & 117.08 \\
Simple ointment & $147.33 \pm 9.0$ & 19.73 \\
\hline
\end{tabular}

"The mean difference is significant $(p<0.05)$ when compared to the left untreated group; ${ }^{a}$ when compared to the simple ointment treated group; $N=6$; Results are expressed as mean \pm SEM 
Table 5 Effect of topical application of ointments containing $4 \%(\mathrm{v} / \mathrm{w})$ essential oil or $5 \%(\mathrm{w} / \mathrm{w})$ resin of Commiphora guidottii on dry weight and hydroxyproline content of the granulation tissue in comparison with nitrofurazone and simple ointment

\begin{tabular}{lll}
\hline Group & Dry weight $(\mathrm{g})$ & Hydroxyproline $(\mu \mathrm{g} / \mathrm{g}$ of tissue) \\
\hline Essential oil & $41.56 \pm 5.71$ & $77.50 \pm 2.46^{*}$ \\
Resin & $63.12 \pm 14.18$ & $63.10 \pm 2.61^{*}$ \\
Nitrofurazone & $44.60 \pm 5.01$ & $134.50 \pm 14.82^{*}$ \\
Simple ointment & $30.38 \pm 2.18$ & $34.00 \pm 1.13$
\end{tabular}

"The mean difference is significant $(p<0.05)$ when compared to the control group; $N=6$; Results are expressed as mean \pm SEM

\section{Discussion}

Characteristic TLC fingerprinting of an extract not only helps in the identification and quality control of a particular plant species but also provides vital information for isolation and identification of chemical marker(s). Thus, TLC fingerprint of the resin of $C$. guidottii given in this work may serve as a reference for proper authentication, standardization and quality control of the plant drug. GCMS analysis confirmed that the major constituents of the essential oil of $C$. guidottii is $\alpha$-santalene, although furanoeudesma-1,3-diene and curzerene also occurred in large amounts (Table 2). Previous report by Craveiro et al. [38] indicates that $\alpha$-santalene along with $\alpha$-bisabolene and furanodiene are the major components of the oil. However, in the present study the later two compounds were detected in lesser amounts.

The wound contraction ability of the oil and resin of scented myrrh observed in this study indicates that the plant possesses a definite pro-healing action, since $88 \%$ of the healing of wound occur due to contraction, and the other $22 \%$ occur due to scar formation [39]. One reason for the wound contraction ability of these plant products could be through enhancing the proliferation of epithelial cells [40]. On the other hand, since incision wound treated with the test samples showed greater tensile strength as compared to the negative control, it might be inferred that the test samples not only increased collagen synthesis per cell, but also aided in crosslinking of the proteins $[3,26,41]$. The common method of collagen determination is based on the quantification of hydroxyproline which accounts for approximately $10 \%$ of the collagen molecule [42, 43]. It is known that collagen accumulation is the sum of synthesis and destruction occurring simultaneously during wound healing process [44]. Therefore, the increased amount of hydroxyproline in the study groups indicates increased collagen content whereas, collagen content in the negative control group was relatively smaller, which might be due to a prolonged inflammatory phase, where the degradation of collagen is greater than its synthesis.

Inflammation induced by carrageenan develops immediately following injections, and produces three distinct phases. The first phase $(0-1.5 \mathrm{~h})$ is mediated by histamine and serotonin. The second phase (1.5-2.5 h) is mediated by bradykinin, while prostaglandins are implied in the third phase $(2.5-5 \mathrm{~h})$. The third phase of oedema is sensitive to most clinically effective antiinflammatory drugs, which have been frequently used to assess the antioedematous effect of natural products $[33,45]$. Accordingly, the resin of C. guidottii showed higher percentage inhibition of oedema formation (>50 \%) $3 \mathrm{~h}$ after injection of carrageenan, which may lead to a conclusion that its anti-inflammatory activity is through inhibition of prostaglandin synthesis.

As shown in Table 7, both the resin and essential oil of C. guidottii displayed broad spectrum antibacterial activity. However, their activity against the Gram-negative bacteria tested was much higher than their effect against the Gram-positive ones. Generally, Gram-negative bacteria are more resistant to antimicrobial agents since they are covered with a phospholipid membrane, carrying the structural lipopolysaccharide component that makes their cell wall impermeable to antimicrobial substances [46]. In the present study, however, higher activity was noted against the Gram-negative bacteria. This might be due to the ability of scented myrrh constituents to affect the overall impermeability and integrity of the bacterial cell wall. In general, the activity obtained may be regarded as highly significant, since plant extracts having MIC values $\leq 8000 \mu \mathrm{g} / \mathrm{mL}$ are considered to be effective antibacterial agents [47]. It is particularly interesting to note that both the oil and resin showed good activity against $S$. aureus $(\mathrm{MIC}=25$ and $50 \mu \mathrm{g} / \mathrm{mL}$, respectively), which is one of the most

Table 6 Anti-inflammatory activity of the resin of Commiphora guidottii on carrageenan-induced mice paw oedema

\begin{tabular}{|c|c|c|c|c|c|}
\hline \multirow[t]{2}{*}{ Test substance } & \multirow[t]{2}{*}{ Dose (mg/kg) } & \multicolumn{4}{|c|}{ Percent oedema inhibition } \\
\hline & & $1 \mathrm{~h}$ & $2 \mathrm{~h}$ & $3 \mathrm{~h}$ & $4 \mathrm{~h}$ \\
\hline & 150 & $9.84 \pm 0.02$ & $32.86 \pm 0.04^{*}$ & $36.23 \pm 0.05^{*}$ & $53.85 \pm 0.03^{*}$ \\
\hline \multirow[t]{2}{*}{ Resin } & 300 & $21.16 \pm 0.007^{*}$ & $44.98 \pm 0.005^{*}$ & $54.83 \pm 0.005^{*}$ & $60.05 \pm 0.009^{*}$ \\
\hline & 600 & $17.20 \pm 0.006^{*}$ & $41.10 \pm 0.007^{*}$ & $52.90 \pm 0.008^{*}$ & $65.44 \pm 0.008^{*}$ \\
\hline Indomthacin & 10 & $27.78 \pm 0.008^{*}$ & $55.00 \pm 0.006^{*}$ & $68.84 \pm 0.008^{*}$ & $86.52 \pm 0.006^{*}$ \\
\hline Vehicle & - & $19.05 \pm 0.002$ & $30.14 \pm 0.006$ & $26.06 \pm 0.005$ & $25.00 \pm 0.006$ \\
\hline
\end{tabular}

"The mean value is significant $(p<0.001)$ when compared with the negative control group; $N=6$; Results are expressed as mean \pm SEM 
Table 7 Minimum inhibitory concentrations (MICs) and zones of inhibition (at a concentration of $200 \mu \mathrm{g} / \mathrm{mL}$ around a $6 \mathrm{~mm}$ disc diameter) of the essential oil and resin of Commiphora guidottii as compared with ciprofloxacin

\begin{tabular}{|c|c|c|c|c|c|}
\hline \multirow[t]{2}{*}{ Bacterial strain } & \multicolumn{2}{|c|}{$\mathrm{MIC}(\mu \mathrm{g} / \mathrm{mL})^{*}$} & \multicolumn{3}{|c|}{ Zone of inhibition (mm) } \\
\hline & Oil & Resin & $\overline{\mathrm{Oil}^{* *}}$ & $\operatorname{Resin}^{* *}$ & Ciprofloxacin \\
\hline Bacillus pumilus 82 & 50 & 200 & $10.5(55.3)$ & $11.0(57.9)$ & 19.0 \\
\hline B. subtilis ATCC6633 & 100 & 200 & $10.0(55.6)$ & $11.0(61.1)$ & 18.0 \\
\hline Escherichia coli 3:37C & 25 & 25 & $14.5(93.5)$ & $14.5(93.5)$ & 15.5 \\
\hline E. coli 306 & 25 & 25 & 15.5 (93.9) & $14.5(87.9)$ & 16.5 \\
\hline E. coli 872 & 25 & 25 & $15.5(96.9)$ & $14.0(87.5)$ & 16.0 \\
\hline E. coli $\mathrm{CD} / 99 / 1$ & 25 & 25 & $16.0(94.1)$ & $15.0(88.2)$ & 17.0 \\
\hline E. coli K88 & 25 & 25 & $16.5(97.1)$ & $14.5(85.3)$ & 17.0 \\
\hline E. coli K99 & 25 & 25 & $16.5(97.1)$ & $14.0(85.3)$ & 16.0 \\
\hline E. coli LT37 & 25 & 25 & $15.0(93.8)$ & $14.0(87.5)$ & 16.0 \\
\hline E. coli ROW 7/12 & 25 & 25 & $16.0(97.0)$ & $14.0(84.8)$ & 16.5 \\
\hline Salmonella typhi Ty2 & 10 & 25 & $15.5(96.9)$ & $16.0(100.0)$ & 16.0 \\
\hline Shigella boydii D13629 & 50 & 100 & $16.5(82.5)$ & $14.5(72.5)$ & 20.0 \\
\hline S. dysentery 1 & 50 & 100 & $16.5(80.5)$ & $14.5(70.7)$ & 20.5 \\
\hline S. dysentery 8 & 50 & 100 & $17.0(81.0)$ & $14.5(69.0)$ & 21.0 \\
\hline S. flexneri Type 6 & 50 & 100 & $16.5(80.5)$ & $15.0(73.2)$ & 20.5 \\
\hline S. soneii 1 & 50 & 100 & $16.0(82.1)$ & $14.0(71.8)$ & 19.5 \\
\hline Staphylococcus aureus ML 267 & 25 & 50 & $11.0(61.1)$ & $15.0(83.3)$ & 18.0 \\
\hline Vibrio cholerae 85 & 10 & 25 & $16.5(91.7)$ & $16.0(88.9)$ & 18.0 \\
\hline V. cholerae 293 & 10 & 25 & $16.5(94.3)$ & $16.0(91.4)$ & 17.5 \\
\hline V. cholerae 1313 & 10 & 25 & $16.0(94.1)$ & $15.5(91.2)$ & 17.0 \\
\hline V. cholerae 1315 & 10 & 25 & $17.0(94.4)$ & 16.5 (91.7) & 18.0 \\
\hline
\end{tabular}

${ }^{*} \mathrm{MICs}$ are expressed as an average from three independent experiments, each performed in triplicate. ${ }^{* *}$ Values in parenthesis indicate $\%$ activity of the test samples compared with that of ciprofloxacin

common bacterial wound pathogens. The antifungal activity of the test samples is also very important in wound healing since fungal superinfection may be present in some cases. More often than not, topical agents providing both antibacterial and antifungal activity are highly desired for wound healing [48]. Postoperative wounds are known to be complicated by infection ultimately delaying angiogenesis $[49,50]$. Microbes can also cause poor quality granulation tissue formation, reduced tensile strength of connective tissue, impaired epithelization and odor [51].
When we look at the phytoconstituents, the wound healing activity of C. guidottii is likely to be attributed to its high content of terpenoids, since terpenoids are known to promote the wound healing process, mainly due to their astringent and antimicrobial properties, which could be responsible for wound contraction and increased rate of epithelization [20]. Sesquiterpene lactones are known to possess antioxidant activity, which may contribute to the wound healing process [49] and triterpenes are also responsible for promotion of rapid wound healing [50].

Table 8 Minimum inhibitory concentrations (MICs) and zones of inhibition (at a concentration of $2000 \mu \mathrm{g} / \mathrm{mL}$ around a $6 \mathrm{~mm}$ disc diameter) of the essential oil and resin obtained from Commiphora guidottii against four fungal strains

\begin{tabular}{|c|c|c|c|c|c|}
\hline \multirow[t]{2}{*}{ Fungal strain } & \multicolumn{2}{|c|}{$\mathrm{MIC}(\mu \mathrm{g} / \mathrm{mL})^{*}$} & \multicolumn{3}{|c|}{ Zone of inhibition (mm) } \\
\hline & Oil & Resin & $\overline{\mathrm{Oil}^{* *}}$ & $\operatorname{Resin}^{* *}$ & Griseofulvin \\
\hline Aspergillus niger ATCC 6275 & 1000 & 1500 & $12.5(83.3)$ & $11.0(73.3)$ & 15 \\
\hline Candida albicans ATCC 10231 & 400 & 1000 & $14.0(87.5)$ & $11.0(68.8)$ & 16 \\
\hline Penicillium funiculosum NCTC 287 & 1000 & 2000 & $12.0(85.7)$ & $10.0(71.4)$ & 14 \\
\hline P. notatum ATCC 11625 & 1000 & 2000 & $12.0(88.9)$ & $10.5(77.8)$ & 13.5 \\
\hline
\end{tabular}

${ }^{*}$ MIC are expressed as an average from three independent experiments, each performed in triplicate. ${ }^{* *}$ Values in parenthesis indicate $\%$ activity of the test samples as compared with that of the standard griseofulvin 
According to Biswas et al. [51], an ideal drug for wound should fulfill the criteria such as rapid contraction of wound leading to quick healing, reduction of wound epithelization time and appreciable gain of tensile strength. It has been reported that a plant based remedy should affect at least two different processes of wound healing before it can be said to have some scientific support for its traditional use as a wound healing agent [52]. In this regard, it is fair to say that the formulated ointments of C. guidotti oil and resin fulfill these criteria as they increased wound contraction and tensile strength besides reducing epithelization time. These results together with the genuine anti-inflammatory and antimicrobial effects observed make these plant products candidates for the development of efficient wound healing drugs, although the reproducibility of some of the experiments could to some degree be affected by the subjectivity involved in some of the observations like skin irritation test and determination of period of epithelization.

\section{Conclusion}

From the foregoing, it can be concluded that the wound-healing potential of scented myrrh may be attributed in full or in part to the presence of terpenoids, which may act individually or possess additive effect that accelerates the healing process. Furthermore, the broad spectrum antimicrobial activities of the oil and the resin as well as the anti-inflammatory effect of the resin may contribute to the overall wound healing capacity of the plant. In view of close similarities between rodents and human biology, and the relative safety of the resin in mice coupled with the mere absence of irritation upon topical application of the formulated ointments on the skin, scented myrrh could be a good candidate for the preparation of natural therapeutic agents for wound management, supporting the its traditional use as a remedy for wounds. However, further studies on histology of tissue obtained from treated group and the expression of growth factors are highly warranted to show the changes in the tissue architectures at different stages of wound healing and to understand the mechanism of action of the resin and the oil in wound healing process, respectively.

\section{Competing interests}

There are no competing interests declared by the authors.

\section{Authors' contributions}

MG conceived the study, and conducted most of the laboratory experiments; analyzed and interpreted experimental results. AM conducted all the antimicrobial studies; KA and DB participated in the proposal, study design and manuscript preparations. PL carried out GC-MS studies and meticulously identified each of the components of the oil. FB performed TLC fingerprinting and corrected the manuscript. All authors read and approved the final manuscript.

\section{Acknowledgements}

One of the authors (MG) would like to acknowledge the Office of Graduate Studies and Research of Addis Ababa University for sponsoring this study and Mekelle University for the study leave. We are also thankful to ENGPME for providing the plant material.

\section{Author details}

'Department of Pharmaceutical Chemistry and Pharmacognosy, School of Pharmacy, College of Health Sciences, Addis Ababa University, P.O. Box 1176, Addis Ababa, Ethiopia. ${ }^{2}$ Department of Pharmaceutical Technology, Noida Institute of Engineering and Technology, 19 Knowledge Park II, Institutional Area, Greater Noida 201306, India. ${ }^{3}$ Divison Pharmaceutical Biology and Pharmacology, Institute of Pharmacy, Martin-Luther-University, Halle-Wittenberg, Hoher Weg 8, D-06120 Halle, Germany. ${ }^{4}$ Department of Pharmacognosy, Institute of Pharmaceutical Sciences, Karl-Franzens University Graz, Universitaetsplatz 4/1, A-8010 Graz, Austria.

Received: 3 December 2014 Accepted: 10 August 2015

Published online: 18 August 2015

\section{References}

1. Martin P. Wound healing aiming for perfect skin regeneration. Science. 1997;276:75-81.

2. Robson MC, Steed DL, Franz MG. Wound healing: biologic features and approaches to maximize healing trajectories. Curr Probl Surgery. 2001;38:72-140.

3. Prasad V, Dorle K. Evaluation of ghee based formulation for wound healing activity. J Ethnopharmacol. 2006;107:38-47.

4. Omale J, Issac AV. Excision and incision wound healing potential of Saba florida (Benth) leaf extract in Rattus novergicus.Int J Pharm Biomed Res. 2010;1:101-7.

5. Pirbalouti AG, Koohpayeh A, Karimi I. The wound healing activity of flower extracts of Punica granatum and Achillea kellalensis in Wistar rats. Acta Pol Pharm. 2010;67:107-10.

6. Thulin M, Claeson P. The botanical origin of scented myrrh (Bissabol or Habak Hadi). Econ Bot. 1991;45:487-94.

7. Claeson P, Samuelsson G. Screening of some Somalian medicinal plants for antidiarrhoeal effects in mice. Phytother Res. 1989;3:180-3.

8. Shen T, Li G-H, Wang X-N, Lou H-X. The genus Commiphora: review of its traditional uses, phytochemistry and pharmacology. J Ethnopharmacol. 2012;142:319-30.

9. Hanuš LO, Řezanka T, Dembitsky V, Moussaieff A. Myrrh - Commiphora chemistry. Biomed Pap Med Fac Univ Palacky Olomouc Czech Repub. 2005;149:3-28.

10. Zygmunt $P$, Claeson P. Inhibitory effects of the sesquiterpene T-cadinol on contractile responses in the isolated guinea-pig ileum. Phytother Res. 1991;5:142-4.

11. Claeson P, Rådström P, Sköld O, Nilsson A, Höglund S. Bactericidal effect of the sesquiterpene T-cadinol on Staphylococcus aureus. Phytother Res. 1992;6:94-8.

12. Andersson $M$, Bergendorff $O$, Shan $R$, Zygmunt $P$, Sterner $O$. Minor components with smooth muscle relaxing properties from scented myrrh (Commiphora guidottii). Planta Med. 1997;63:251-4.

13. Institute for Laboratory Animal Research (ILAR). Guide for the Care and Use of Laboratory Animals. Washington D.C.: National Academy Press; 1996.

14. Trease GE, Evans WC. A Text Book of Pharmacognosy. 13th ed. London: Bailliére Tindall; 1989

15. Adams RP. Identification of Essential Oil Components by Gas Chromatography/Mass Spectrometry. 4th ed. Illinois: Allured Publ Corp; 2007.

16. Jordán MJ, Margaría CA, Shaw PE, Goodner KL. Volatile components and aroma active compounds in aqueous essence and fresh pink guava fruit puree (Psidium guajava L.) by GC-MS and multidimensional GC/GC-O. J Agric Food Chem. 2003;51:1421-6.

17. Hazzit M, Baaliouamer A, Faleiro ML, Miguel MG. Composition of the essential oils of Thymus and Origanum species from Algeria and their antioxidant and antimicrobial activities. J Agric Food Chem. 2006;54:6314-21.

18. Oliveira AL, Lopes RB, Cabral FA, Eberlin MN. Volatile compounds from pitanga fruit (Eugenia uniflora L.). Food Chem. 2006;99:1-5. 
19. Jones P, Kinghorn D. Extraction of plant secondary metabolites. In: Sarker D, Latif Z, Gray A, editors. Methods in Biothechnology of Natural Products Isolation. 2nd ed. New Jersey: Humana Press; 2006

20. Sasidharan S, Nilawatyi R, Xavier R, Latha L, Amala R. Wound healing potential of Elaeis guineensis Jacq leaves in an infected albino rat model. Molecules. 2010:15:3186-99.

21. Gatsing D, Aliyu R, Kuiate R, Garba H, Jaryum H, Tedongmo N, et al. Toxicological evaluation of the aqueous extract of Allium sativum bulbs on laboratory mice and rats. Cameroon J Exp Biol. 2005;1:39-45.

22. Nair SS, Mathew M, Sreena K. Evaluation of skin irritation of herbal antioxidant cream. Asian J Biochem Pharm Res. 2012;2:184-9.

23. Draize J. Appraisal of the Safety of Chemicals in Foods, Drugs and Cosmetics. Association Food Drug Officials USA. 1959;49:2-56.

24. British Pharmacopoeia. Department of Health and Social Security Scottish Home and Health Department, Office of the British Pharmacopoeia Commission, UK. 1988, 2: 713

25. Barua CC, Talukdar A, Begum SA, Sarma DK, Fathalk DC, Barua AG, et al. Wound healing activity of methanolic extract of leaves of Alternanthrea brasiliana Kuntz using in vivo and in vitro model. Indian J Exp Biol. 2009;47:1001-5.

26. Agarwal PK, Singh A, Gaurav K, Goel S, Khanna HD, Goel RK. Evaluation of wound healing activity of extracts of plantain banana (Musa sapientum var paradisiaca) in rats. Indian J Exp Biol. 2009:47:32-40.

27. Annan K, Dickson R. Evaluation of wound healing actions of Hoslundia opposite Vahl, Anthocleista nobilis G. Don. and Balanites aegyptiaca L. J Sci Technol. 2008;28:26-35.

28. Kokane DD, More RY, Kale MB, Nehete MN, Mehendale PC, Gadgoli CH. Evaluation of wound healing activity of root of Mimosa pudica. J Ethnopharmacol. 2009;124:311-5.

29. Akkol EK, Süntar I, Orhan IE, Keles H, Kan A, Çoksari G. Assessment of dermal wound healing and in vitro antioxidant properties of Avena sativa L. J Cereal Sci. 2011:53:285-90.

30. Leach AA. Notes on a modification of the Neuman and Logan method for the determination of the hydroxyproline. Biochem J. 1960;74:70-1.

31. Gurung S, Skalko-Basnet N. Wound healing properties of Carica papaya latex: in vivo evaluation in mice burn model. J Ethnopharmacol. 2009;121:338-41.

32. Padilha MM, Vilela FC, Rocha CQ, Dias MJ, Soncini R, dos Santos MH, et al. Anti-inflammatory properties of Morus nigra leaves. Phytother Res. 2010;24:1496-500

33. Marrassini C, Acevedo C, Miño J, Ferraro G, Gorzalczany S. Evaluation of antinociceptive, anti-inflammatory activities and phytochemical analysis of aerial parts of Urtica urens L. Phytother Res. 2010;24:1807-12.

34. Mitchell J, Carter W. Modeling antimicrobial activity of CloroxR using an agar-diffusion test: a new twist on an old experiment. Bioscene. 2000;26:9-13.

35. Clinical and Laboratory Standards Institute. Method for Antimicrobial Susceptibility Testing of Aanaerobic Bacteria. Approved standard, 7th edition. 2006, 26:2

36. EPA (US) Dermal Classification System. Federal Insecticide, Fungicide, Rodenticide Act, Pesticide Assessment Guidelines, Subdivision F: Hazard evaluation: humans and domestic animals. Addendum 3 on data reporting; 1988.

37. Mekonnen $Y$, Dekebo A, Dagne. Toxicity study in mice of resins of three Commiphora species. SINET: Ethiop J Sci. 2003;26:151-3.

38. Craveiro A, Corsano S, Proietti G, Strappaghetti G. Constituents of essential oil of Commiphora guidottii. Planta Med. 1983;48:97-8.

39. Ejaz S, Chekarova I, Cho JW, Lee SY, Ashraf S, Lim SW. Effect of aged garlic extract on wound healing: a new frontier in wound management. Drug Chem Toxicol. 2009;32:191-203.

40. Getie M, Gebre-Mariam T, Rietz R, Höhne C, Huschaka C, Schmditke M, et al. Evaluation of the antimicrobial and anti-inflammatory activities of the medicinal plants Dodonaea viscosa, Rumex nervosus and Rumex abyssinicus. Fitoterapia. 2003;74:139-43

41. Wang JP, Ruan JL, Cai YL, Luo Q, Xu HX, Wu YX. In vitro and in vivo evaluation of the wound healing properties of Siegesbeckia pubescens. J Ethnopharmacol. 2011;134:1033-8.

42. Nayak S, Nalabothu P, Sandiford S, Bhogadi V, Adogwa A. Evaluation of wound healing activity of Allamanda cathartica L. and Laurus nobilis L. extracts on rats. BMC Complem Altern Med. 2006;6:12.

43. Taşkiran D, Taşkiran E, Yercan H, Kutay FZ. Quantification of total collagen in rabbit tendon by the Sirius Red method. Turkish J Med Sci. 1999;29:7-9.
44. Iyyam Pillai S, Palsamy P, Subramanian S, Kandaswamy M. Wound healing properties of Indian propolis studied on excision wound-induced rats. Pharm Biol. 2010;48:1198-2106.

45. Di Rosa M, Giroud JP, Willoughby DA. Studies of the mediators of the acute inflammatory response induced in rats in different sites by carrageenan and turpentine. J Pathol. 1971;104:15-29.

46. Patrone JB, Stein DC. Effect of gonococcal lipooligosaccharide variation on human monocytic cytokine profile. BMC Microbiol. 2007:7:7

47. Raina R, Prawez S, Verma PK, Pankaj NK. Medicinal plants and their role in wound healing. Vet Scan. 2008;3:2.

48. Gupta AK, Cooper EA. Update in antifungal therapy of dermatophytosis. Mycopathologia. 2008;166:353-67.

49. Pradhan D, Panda P, Tripathy G. Wound healing activity of aqueous and methanolic bark extracts of Vernonia arborea Buch.-Ham. in wistar rats. Nat Prod Rad. 2009:8:6-11.

50. Deshmukh PT, Fernandes J, Atul A, Toppoa E. Wound healing activity of Calotropis gigantea root bark in rats. J Ethnopharmacol. 2009:125:178-81.

51. Biswas TK, Auddy B, Bhattacharya NP, Bhattacharya S, Mukherjee B. Wound healing activity of human placental extracts in rats. Acta Pharmacol Sin. 2001;22:1113-6.

52. Houghton PJ, Hylands PJ, Mensah AY, Hensel A, Deters AM. In vitro tests and ethnopharmacological investigations: wound healing as an example. J Ethnopharmacol. 2005;100:100-7.

\section{Submit your next manuscript to BioMed Central and take full advantage of:}

- Convenient online submission

- Thorough peer review

- No space constraints or color figure charges

- Immediate publication on acceptance

- Inclusion in PubMed, CAS, Scopus and Google Scholar

- Research which is freely available for redistribution 